\title{
IDIOPATHIC NEONATAL HYPERGLYCAEMIA
}

\author{
BY \\ SHEILA R. LEWIS and PATRICIA E. MORTIMER* \\ From the South London Hospital, S.W.4, and the London Hospital, Turner Street, London
}

(RECEIVED FOR PUBLICATION FEBRUARY 5, 1964)

Attention has recently been drawn to a temporary diabetic state in newborn infants with complete recovery in weeks or months (Hutchison, Keay, and Kerr, 1962; Sweetnam and Sykes, 1962). Infants with this condition exhibit little or no ketosis and have low insulin requirements compared with true diabetes mellitus presenting at this age (Guest, 1949; Gans, 1954; Hofman-Bang, 1954). The condition is a separate entity from the hyperglycaemia seen in association with infections and cerebral abnormalities. For these reasons we suggest the use of the term 'idiopathic neonatal hyperglycaemia'.

The paucity of published material on this subject since 1850 suggests that such cases are rare, but we have learnt of several treated by colleagues in the past 12 months, and some cases may pass unrecognized. We consider that the condition is more common than has previously been supposed.

Early recognition and careful treatment are necessary in the more severe cases if sequelae are to be avoided. We therefore feel justified in reporting two cases, together with a brief review of the published material.

\section{Case Reports}

Case 1. A male first child of healthy parents; there is no family history of diabetes mellitus. He was born on Jily 29, 1962, after a normal pregnancy by breech delivery, following surgical induction of labour at 42 weeks gestation. Delivery was not difficult; the placenta was described as 'very infarcted'.

His birth weight was $4 \mathrm{lb} .6 \mathrm{oz}$. (1.98 kg.) and he made good progress, feeding well from the breast until the 7th day, when he developed mild diarrhoea and vomiting. There was no weight loss until the 10th day, when he lost $2 \mathrm{oz}$. $(57 \mathrm{~g}$.). Routine examination of the urine showed a reducing substance, identified chromatographically as glucose. Breast milk was insufficient and artificial feeding was introduced. He was transferred to the South London Hospital at the age of 12 days.

On admission he weighed $4 \mathrm{lb} .8 \mathrm{oz} .(2.08 \mathrm{~kg}$.) and showed the characteristic appearance of dysmaturity.

\footnotetext{
- Present Address: Chase Farm Hospital. Enfield.
}

He was vigorous and not dehydrated. Blood sugar (two and a half hours after a feed) was $465 \mathrm{mg}$./100 ml.; urine sugar $2 \%$; acetone nil. The glucose tolerance test at 3 weeks gave the following results: fasting $115 \mathrm{mg}$. $/ 100 \mathrm{ml}$.; $\frac{1}{2}$ hour $153 \mathrm{mg}$.; 1 hour $200 \mathrm{mg}$.; $1 \frac{1}{2}$ hours $175 \mathrm{mg}$.; and 2 hours $200 \mathrm{mg} . / 100 \mathrm{ml}$.

Serum electrolytes were normal. No pathogens were isolated from rectal swabs. Urinary 17-ketosteroids were $0.3 \mathrm{mg}$./24 hours; and 17-ketogenic steroids were $0.73 \mathrm{mg} . / 24$ hours. There was no serum insulin-like activity at age 6 weeks.

He continued to have slightly loose stools, which improved on oral neomycin. Half cream milk was given, and he gained weight until the age of 5 weeks, at which time he weighed $6 \mathrm{lb}$. $(2.73 \mathrm{~kg}$.) (637 g. above birth weight). This rate of progress was not maintained and did not improve when sugar was omitted from his feeds, the calorie requirement being made up with milk powder. Oocasional pyrexial episodes responded to oral fluids, and were attributed to polyuria.

At the age of 9 weeks he weighed only $5 \mathrm{lb} .15 \mathrm{oz}$. $(2.7 \mathrm{~kg}$.) and insulin treatment was started. In view of the importance of avoiding hypoglycaemia (Hutchison et al., 1962; Brown and Wallis, 1963), treatment was begun with small doses of soluble insulin, $0 \cdot 2$ units after each feed, i.e. 1.2 units a day. This resulted in a weight gain of $15 \mathrm{oz}$ ( $425 \mathrm{~g}$.) in one week. There was little further weight gain until the dose of insulin had been increased to 1 unit after each feed, i.e. 6 units a day. A weaning diet and full cream milk were introduced at $\mathbf{1 6}$ weeks.

At the age of 17 weeks, 4 consecutive insulin doses were omitted. His weight fell by $10 \mathrm{oz}$. $(283.5 \mathrm{~g}$.) and his temperature rose to $102^{\circ} \mathrm{F}$. $\left(39^{\circ} \mathrm{C}\right.$.). The blood sugar was $1,028 \mathrm{mg} . / 100 \mathrm{ml}$. and alkali reserve $15.3 \mathrm{mEq} / 1$. He was given soluble insulin, 1 unit, and rehydrated $(N / 2$ saline subcutaneously and a milk feed). Five hours later the blood sugar had fallen to $534 \mathrm{mg}$. $/ 100 \mathrm{ml}$.

Subsequent progress was interrupted only by minor upper respiratory infections and on one occasion by vomiting, which appeared to be associated with teething.

At the age of 8 months he weighed $13 \mathrm{lb} .10 \mathrm{oz}(6 \cdot 2 \mathrm{~kg}$.) and an intravenous tolbutamide test was performed (Fig. 1). This showed a significant fall in blood sugar suggesting the presence of functioning islet-cell tissue.

At the age of 15 months he was having 8 units of insulin a day in three divided doses and was below the 3rd 


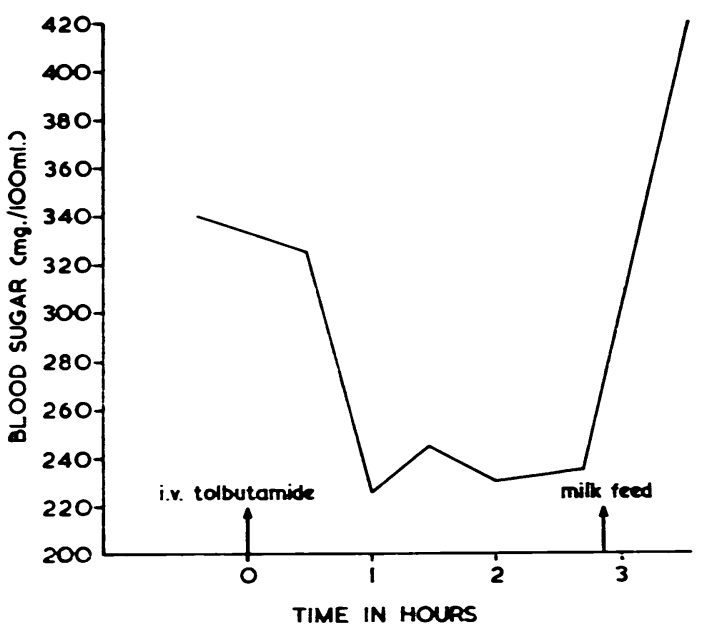

Fig. 1.-Case 1. Intravenous tolbutamide test $(15 \mathrm{mg} . \mathrm{kg}$.) at 8 months, showing fall of blood sugar after 1 hour.

percentile for height and weight $(27$ in. $(68.5 \mathrm{~cm}$.$) and$ $17 \mathrm{lb} .5 \mathrm{oz} .(7 \cdot 85 \mathrm{~kg}$.) respectively). It was clear that the dose of insulin was inadequate and he was admitted for restabilization. He walked with help and had a vocabulary of five or six words (sometimes using two, e.g. "bad boy") and he handled toys well. Insulin was increased to 16 units in two doses and this resulted in a weight gain of $2 \mathrm{lb} .5 \mathrm{oz}$. $(1,055 \mathrm{~g}$.) in one month.

COMMENT. Treatment has been directed throughout to maintain a satisfactory weight increase and to avoid hypoglycaemia, with its attendant risk of irreversible brain damage. From assessment at the age of 15 months, it seems that while we have achieved the second objective, we have fallen short of the first. It remains to be seen whether he will reach normal stature. Though the complete recovery implicit in the diagnosis has not yet been confirmed in this child, we feel confident in including him in this group of cases for the following reasons.

(1). The low birth weight and post-maturity in common with 12 previous cases.

(2). The degree of response to insulin shown by the weight gain following the introduction of relatively small doses of insulin, and the fall of blood sugar from 1,028 to $534 \mathrm{mg}$. $100 \mathrm{ml}$. following 1 unit of insulin.

(3). The absence of ketosis at the onset of the disease and the relatively minor degree of ketosis associated with a high blood sugar when insulin was withheld.

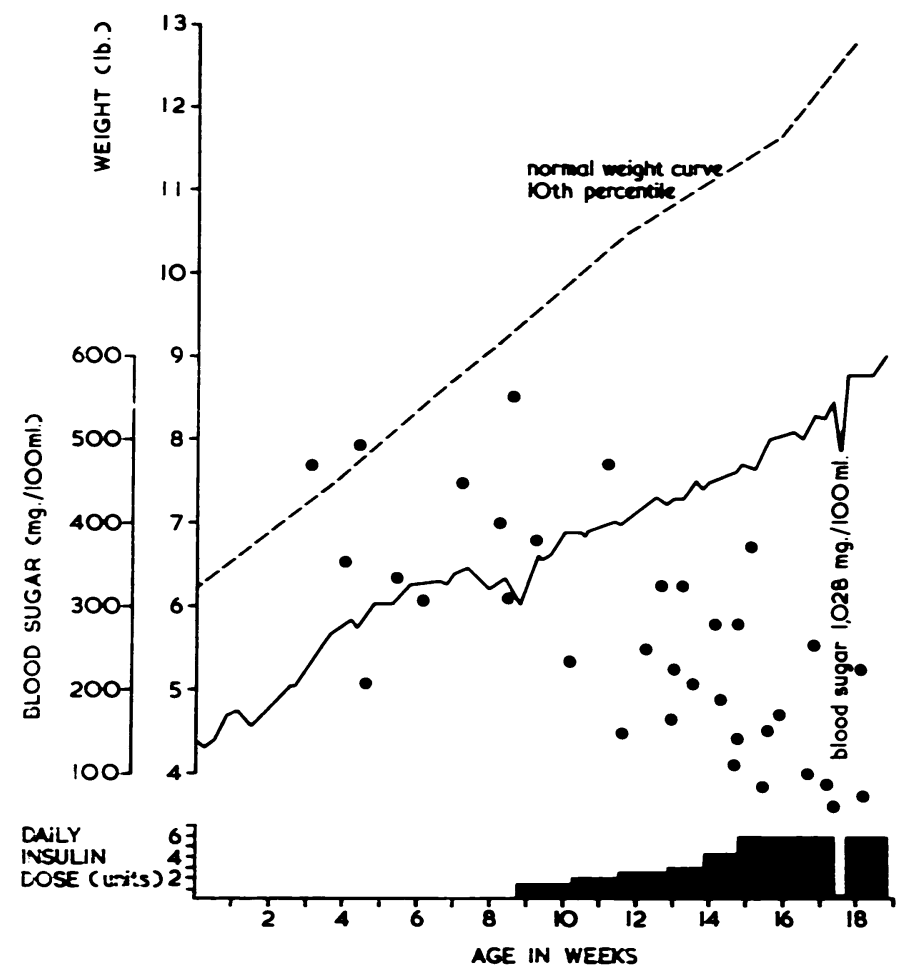

Fic. 2.-Case 1. Progress chart showing weight curve, insulin therapy, and blood sugars. 
(4). The tolbutamide test at 8 months suggests recovering pancreatic function.

There is no evidence at present of any complications of hyperglycaemia and the serum cholesterol is normal (155 mg./100 ml.), but a closer control of the blood sugar level must be attempted for as long as he needs insulin. Fig. 2 shows the progress up to $4 \frac{1}{2}$ months.

Case 2. This fourth child of a healthy Ghanaian family was born normally on December 25,1962 at the London Hospital at 38 weeks gestation, there having been mild hydramnios. She weighed $7 \mathrm{lb} .(3 \cdot 17 \mathrm{~kg}$.) and seemed shocked and pale at birth but required no resuscitation. After 9 hours she became oedematous and cold (rectal temperature $93^{\circ}$ F. $\left(33 \cdot 9^{\circ}\right.$ C.)). The hypothermia was satisfactorily corrected, and in the next three days a diuresis occurred, resulting in loss of oedema fluid and $1 \mathrm{lb}$. (453 g.) in weight. She then appeared healthy, but failed to gain, despite an adequate intake from the breast. On the twelfth and thirteenth days complementary feeds were given by tube, and this was followed by dramatic weight loss to $5 \mathrm{lb}$. $(2 \cdot 26 \mathrm{~kg}$.) associated with polyuria.

On examination she was lively, thirsty, bright-eyed, but grossly dehydrated, though still passing urine.

Investigations showed a blood sugar of $890 \mathrm{mg} . / 100 \mathrm{ml}$. (true glucose $840 \mathrm{mg} . / 100 \mathrm{ml}$.) and heavy glycosuria, but no acidosis or ketonuria.

Treatment was instigated with intravenous half-normal saline and intramuscular soluble insulin 5 units.

Two hours later the blood sugar was $720 \mathrm{mg}$. $/ 100 \mathrm{ml}$., and after four hours it was $130 \mathrm{mg}$. $/ 100 \mathrm{ml}$. At this time generalized convulsions developed. These were temporarily relieved by $11 \mathrm{~g}$. glucose intravenously, but recurred frequently and were not relieved by calcium, sedation, or further glucose; they ceased spontaneously after 36 hours, by which time small milk feeds were being tolerated. The blood sugar varied from 300 to $600 \mathrm{mg} . / 100 \mathrm{ml}$., the serum calcium and other electrolytes remained within normal limits, and in $\mathbf{2 4}$ hours the hydration was restored to normal. (The serum magnesium level was not measured.) Three small doses of insulin (total 0.8 units) were given during this time in an attempt to reduce the osmotic diuresis, and thereby improve the hydration and lessen the electrolyte loss. The EEG remained normal throughout, but the infant did not exhibit normal neurological responses for 7 days.

She sucked well, however, and breast feeding was soon re-established, but she failed to gain during three days without insulin. Soluble insulin $0 \cdot 1$ units every 4 hours was therefore given with feeds, increasing over the next few weeks to an average of 6 units a day in order to maintain a satisfactory weight gain. Two episodes of ketosis with minimal acidosis, one lasting 12 hours, the other almost three days, responded to extra insulin and $M / 6$ sodium lactate solution by mouth. No attempt was made to eliminate glycosuria or hyperglycaemia, which persisted to 10 weeks of age. The blood sugar having gradually fallen to the region of $100 \mathrm{mg} . / 100 \mathrm{ml}$., insulin was withdrawn at this stage for the purpose of investiga-

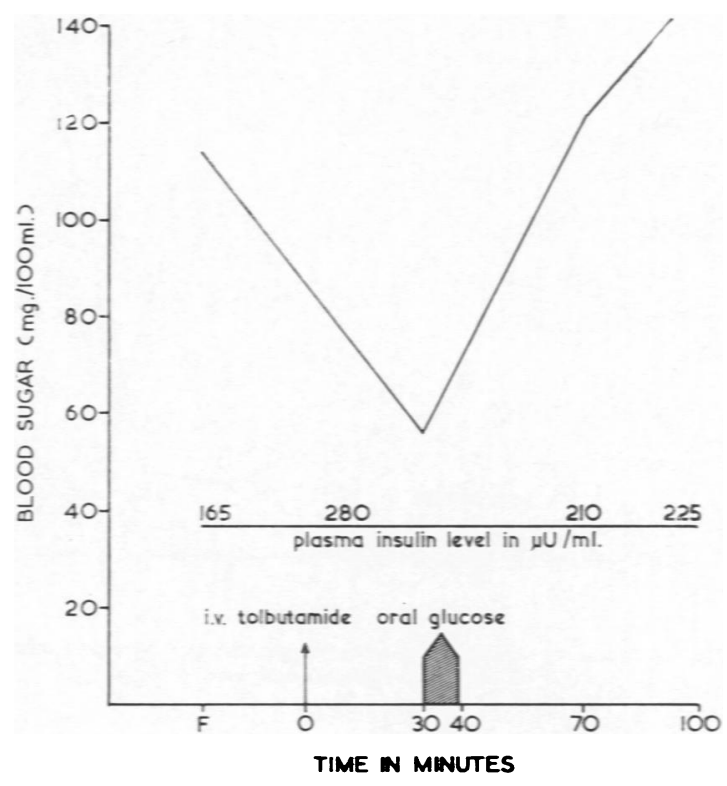

FIG. 3.-Case 2. Intravenous tolbutamide test (15 mg./kg.) showing fall of blood sugar and rise of plasma insulin levels (at 10 weeks).

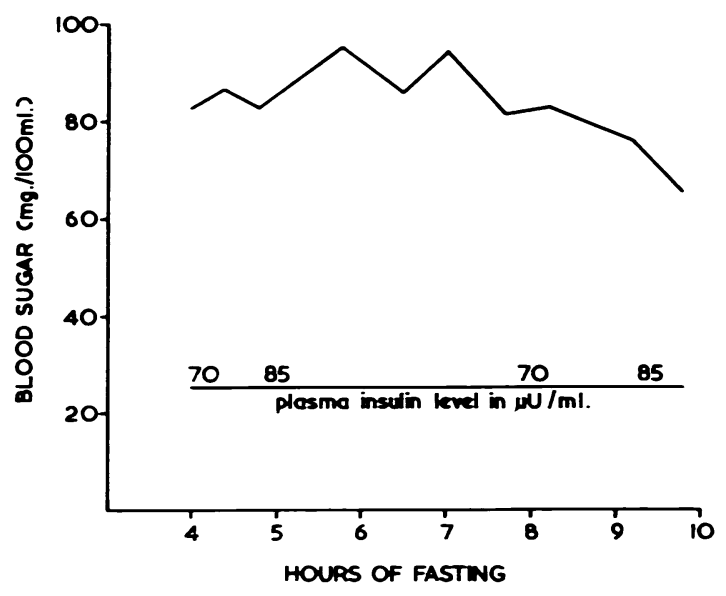

FIG. 4.-Case 2. Blood sugar and plasma insulin levels during a 10-hour fast at $10 \frac{1}{2}$ weeks of age.

tion and found to be no longer necessary. She now weighed $9 \mathrm{lb} .1 \mathrm{oz}$. (4.1 kg.).

Plasma insulin levels were estimated at $10 \frac{1}{2}$ weeks, when insulin had been withdrawn for three days. A very high fasting level was found $(165 \mu \mathrm{U}$./ml.) with a further rise after intravenous tolbutamide and after oral glucose (Fig. 3); hypoglycaemia did not develop during a prolonged starvation period (Fig. 4). Insulin antibodies were demonstrated in the plasma.

At 12 weeks a glucose tolerance test was normal and the plasma insulin levels were also recorded (Fig. 5). 


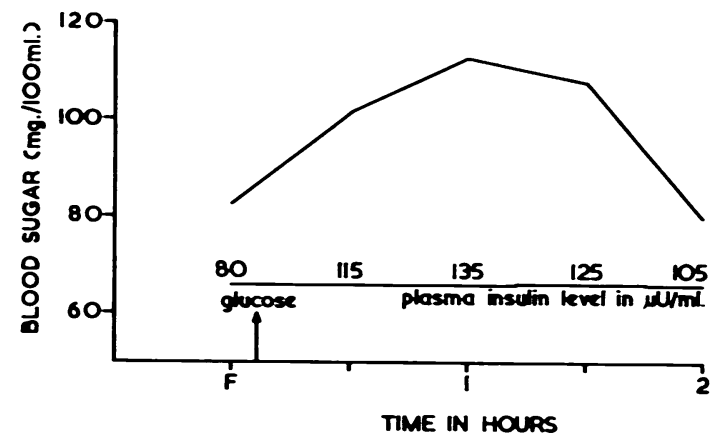

Fig. 5.-Case 2. Glucose tolerance test at 11 weeks of age showing blood sugar and plasma insulin levels.

The child did not smile until 10 weeks, or 'coo' until 11 weeks, and slight spasticity in the limbs was found from time to time. Brain damage was suspected, but at 6 months she was sitting well without support, seemed normal in every way, and weighed $17 \mathrm{lb} .7 \mathrm{oz}$. (7.9 kg.). By 8 months she was attempting to stand and walk, and no abnormalities were detected clinically or by electroencephalography.

She was breast fed for five weeks and then changed to full-cream dried milk without added sugar, the addition of carbohydrate food to the diet being delayed until the age of 3 months.

Fig. 6 shows her progress to 13 weeks.
Discussion

The features of idiopathic neonatal hyperglycaemia are sufficiently characteristic to constitute a distinct clinical picture. There is hyperglycaemia with consequent polyuria, polydipsia, and dehydration, but without proportionate ketosis; and this is followed by eventual recovery to normal glucose tolerance.

The 13 published cases of idiopathic transient hyperglycaemia, together with our two cases, are summarized in the Table. They all presented by the age of 6 weeks, and all but three were diagnosed in the first 4 weeks of life. Two had severe associated disease (Cases 2 and 3) which, it may be argued, provoked the diabetic-like state; however, gangrene (Case 2) or abscess (Case 3) may equally well have been the result of hyperglycaemia.

Six other cases of neonatal hyperglycaemia have been recorded, all of which died. Four of these we have excluded because they showed pancreatic abnormalities at post-mortem examination (Limper and Miller, 1935; Lewis and Eisenberg, 1935; Devine, 1938; Cuno, 1911). The other two may have fitted the category of idiopathic hyperglycaemia and may have proved temporary had the infants survived; one died before insulin was discovered (Kitselle, 1852), and the other shortly after the onset of treatment (Hickish, 1956).

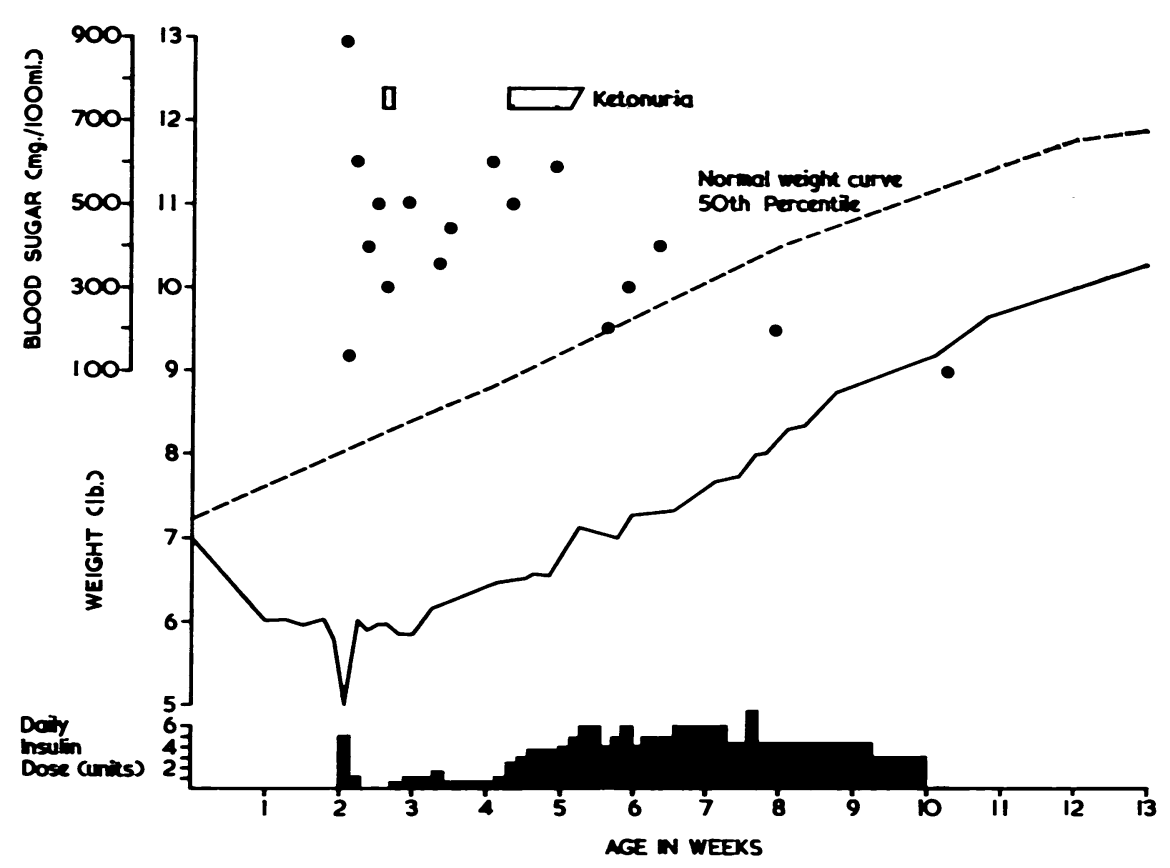

Fig. 6. - Case 2. Progress chart showing weight curve, insulin therapy, and blood sugar levels. 
TABLE

IDIOPATHIC HYPERGLYCAEMIA

\begin{tabular}{|c|c|c|c|c|c|c|c|c|c|}
\hline $\begin{array}{l}\text { Case } \\
\text { No. }\end{array}$ & Reference & $\begin{array}{l}\text { Age } \\
\text { at } \\
\text { Onset } \\
\text { (days) }\end{array}$ & Sex & $\begin{array}{l}\text { Birth } \\
\text { Weight } \\
\text { (kg.) }\end{array}$ & $\begin{array}{c}\text { Matur- } \\
\text { ity } \\
\text { (wk.) }\end{array}$ & $\begin{array}{c}\text { Highest } \\
\text { Blood } \\
\text { Sugar } \\
\text { (mg. } \\
100 \mathrm{ml} \text {. }\end{array}$ & Ketonuria & Associated Condition & $\begin{array}{c}\text { Insulin } \\
\text { Duration }\end{array}$ \\
\hline$\frac{1}{2}$ & $\begin{array}{l}\text { Ramsey (1927) } \\
\text { Lawrence and } \\
\text { McCance (1931) }\end{array}$ & $\begin{array}{l}30 \\
18\end{array}$ & $\underset{\mathbf{F}}{\mathbf{M}}$ & $2 \cdot 2$ & $\begin{array}{l}40 \\
40\end{array}$ & 600 & $\begin{array}{l}\text { Nil } \\
\text { Nil }\end{array}$ & $\begin{array}{c}\text { Nil } \\
\text { Gangrene }\end{array}$ & 7 days \\
\hline 3 & Strandqvist (1932) & 35 & $\mathbf{M}$ & $2 \cdot 2$ & 40 & 420 & Nil & $\begin{array}{l}\text { Abscess surrounding } \\
\text { gangrene }\end{array}$ & 2 weeks \\
\hline $\begin{array}{l}4 \\
5 \\
6\end{array}$ & $\begin{array}{c}\text { Arey (1953) } \\
\text { Keidan (1955) } \\
\text { Nawrocka-Kanska } \\
(1952)\end{array}$ & $\begin{array}{l}13 \\
22 \\
12\end{array}$ & $\begin{array}{l}\mathbf{M} \\
\mathbf{F} \\
\mathbf{M}\end{array}$ & $\begin{array}{l}2 \cdot 2 \\
2 \cdot 78 \\
2 \cdot 7\end{array}$ & $\begin{array}{c}40 \\
40 \\
\text { Not } \\
\text { recorded }\end{array}$ & $\begin{array}{l}555 \\
240 \\
268\end{array}$ & $\begin{array}{c}\text { Nil } \\
\text { Once } \\
\text { Yes }\end{array}$ & $\begin{array}{c}\text { Pyrexia } \\
\text { "Boil" } \\
\text { Vomiting. ? cerebral } \\
\text { hae.norrhage }\end{array}$ & $\begin{array}{l}6 \text { weeks } \\
\text { Not given } \\
\text { Not given }\end{array}$ \\
\hline 7 & $\begin{array}{l}\text { Engleson and } \\
\text { Zetterqvist (1957) }\end{array}$ & 5 & $\mathbf{M}$ & $2 \cdot 78$ & $40+$ & 720 & Nil & & 3 months \\
\hline 8 & $\begin{array}{c}\text { Engleson and } \\
\text { Zetterqvist (1957) }\end{array}$ & 11 & $\mathbf{F}$ & $2 \cdot 02$ & 40 & 400 & Nil & & 27 weeks \\
\hline $\begin{array}{c}9 \\
10 \\
11 \\
12\end{array}$ & $\begin{array}{l}\text { Hutchison et al. (1962) } \\
\text { Hutchison et al. (1962) } \\
\text { Hutchison et al. (1962) } \\
\text { Hutchison et al. (1962) }\end{array}$ & $\begin{array}{c}7 \\
17 \\
12 \\
42 \\
\text { (sooner) }\end{array}$ & $\begin{array}{l}\mathbf{F} \\
\mathbf{F} \\
\mathbf{F} \\
\mathbf{F}\end{array}$ & $\begin{array}{l}1 \cdot 93 \\
2 \cdot 4 \\
2 \cdot 13 \\
1 \cdot 84\end{array}$ & $\begin{array}{l}40 \\
40 \\
36 \\
43\end{array}$ & $\begin{array}{r}1.292 \\
666 \\
800 \\
750\end{array}$ & $\begin{array}{l}\text { Nil } \\
\text { Nil } \\
\text { Nil } \\
\text { Nil }\end{array}$ & $\begin{array}{c}\text { Ethisterone effect } \\
\text { Nil }\end{array}$ & $\begin{array}{l}41 \text { months } \\
18 \text { months } \\
22 \text { days } \\
2 \text { weeks }\end{array}$ \\
\hline 13 & Sweetnam and Sykes & $\begin{array}{l}14 \text { (or } \\
\text { sooner) }\end{array}$ & $\mathbf{F}$ & $1 \cdot 54$ & 40 & 1.200 & Mild & & 8 months \\
\hline 14 & Present paper: Case 1 & 7 & $\mathbf{M}$ & $1 \cdot 98$ & 42 & 1.028 & Tr. & Mild gastro-enteritis & $\begin{array}{l}\text { At least } \\
15 \text { months }\end{array}$ \\
\hline 15 & Present paper: Case 2 & 13 & $\mathbf{F}$ & $3 \cdot 17$ & 38 & 980 & Yes & Oedema & 8 weeks \\
\hline
\end{tabular}

The case described by Jeune and Riedweg (1960) had associated gastro-enteritis due to a specific type of Esch. coli, severe acidosis, and stupor with blood-stained cerebrospinal fluid. It is difficult to postulate that hyperglycaemia of two days' duration was the primary factor in this child's illness.

Since 1850 there have been only three reports of true diabetes mellitus with such early onset, i.e. 11,21 , and 39 days, respectively (Guest, 1949; Hofman-Bang, 1954; and Gans, 1954). These cases differ strikingly from those with idiopathic hyperglycaemia. Two had severe ketosis, and the third was diagnosed by the mother, who, having other diabetic children, found glucose in the urine wrung out from the napkin before symptoms appeared. A strong family history was present in two cases.

Aetiology. Definite dysmaturity was present in all but 4 cases, there being a very low birth weight for gestation period in 11 . Of the remaining 4 cases, 2 (Cases 5 and 7) weighed only $6 \mathrm{lb} .2 \mathrm{oz}$. (2,777 g.) at term, and one of these (Case 7) was described as post-mature.

Both sexes were equally affected, and a family history of diabetes mellitus was recorded in two (Cases 1 and 13).

Cerebral damage appears to play little part in the causation of this syndrome. It was considered necessary to examine the cerebrospinal fluid in only 4 cases: Keidan's case had xanthochromic, bloodstained fluid with the protein rising to $1,000 \mathrm{mg}$. $/ 100$ ml.; Nawrocka-Kanska's case showed a raised protein and xanthochromia; Engleson mentioned the sugar but did not record the other findings, and one of the cases described by Hutchison et al. had a protein level of $80 \mathrm{mg}$. $100 \mathrm{ml}$. Keidan (1955) was unable to explain the significance of the cerebrospinal fluid changes, but Nawrocka-Kanska (1952) considered the cerebral haemorrhage to be the fundamental cause. However, neither of the two infants described here exhibited signs of cerebral damage before or during the development of hyperglycaemia, nor was this a feature in the other 10 cases. If cerebral damage were a significant aetiological factor, one would expect symptoms of hyperglycaemia to be common in babies with cerebral birth trauma, and this is not so. The transient glycosuria secondary to cerebral lesions is usually due to a lowered renal threshold.

Insulin Studies. There are no previous insulin studies in these infants. Plasma insulin activity has been satisfactorily demonstrated in the normal newborn and in infants of diabetic mothers by the rat diaphragm technique (Baird and Farquhar, 1962; Stimmler, Brazie, and O`Brien, 1964).

Dr. Keith Taylor kindly undertook estimations of serum insulin activity in Case 1 (M.A.) before the start of insulin therapy and in two healthy infants, one of whom was dysmature. He reports, 'no insulin was detectable in M.A.'s serum by the rat diaphragm method. The serum was a post-prandial specimen, and serum insulin was by contrast readily detectable in the serum of the two healthy infants, the amount present being comparable to that seen in normal adults. It cannot of course be certain in 
these experiments whether insulin was absolutely deficient or was present and masked by antagonistic factors in the serum of the hyperglycaemic child.'

The studies in Case 2 (E.M.S.) were performed by Dr. Ellis Samols by immuno assay. Very high levels of insulin activity were demonstrated. The fasting level of 165 units three days after withdrawal of insulin treatment, fell to 80 units a week later. Remaining exogenous insulin may have contributed to this and the interpretation of the results was further complicated by the presence of insulin antibodies resulting from previous therapy.

However, Dr. Samols thought it fair to conclude that: 'there was a rise in insulin after tolbutamide and there was a rise in insulin after glucose.'

Though our findings do not shed much light on the basic lesion, the following points emerge. The failure to demonstrate insulin activity in the serum of Case 1 at 6 weeks may be taken as evidence either of defective insulin production or of the presence of insulin antagonists. The response to intravenous tolbutamide, i.e. the fall of blood sugar in both infants and the rise of insulin activity in Case 2, suggests either recovery of pancreatic function or a decrease of insulin antagonists; Case 2 had at this stage recovered clinically.

Following the intravenous tolbutamide test in Case 1 the possibility of treatment with tolbutamide was considered. It seemed, however, that if a gradual recovery of islet cell function were taking place, stimulation of insulin release might 'exhaust' the pancreas and hinder recovery. Treatment with tolbutamide failed in one of Hutchison's cases.

Treatment and Sequelae. Keidan (1955) drew attention to the low insulin requirements of these babies compared with those in true diabetes mellitus and doubted whether insulin was necessary. However, neither of our cases thrived without it and the effect of withholding it in Case 1 at the age of 4 months clearly demonstrated the need for its continued use. The mild episodes of ketosis in Case 2 were taken as an indication for increasing the dose of insulin to which they responded.

Hutchison $e t$ al. were the first to describe permanent sequelae in these infants, but few other authors have reported a comparable follow-up. Hypoglycaemia in the newborn period is known to be a cause of permanent brain damage (Brown and Wallis, 1963; Neligan, Robson, and Watson, 1963). As Sweetnam and Sykes state, hypoglycaemia at any time during the stage of rapid brain growth is likely to be particularly dangerous in this respect. Hutchison et al. considered that hypoglycaemic insulin reactions were responsible for the mental retardation of two of their cases, though they do not accept the possibility in their third defective child.

Whether or not hypoglycaemia resulting from the too liberal use of insulin is the only cause of brain damage it seems imperative to avoid it. We think that treatment should be aimed at the maintenance of a normal rate of growth rather than the elimination of hyperglycaemia and glycosuria, Neither of these two cases developed the cushingoid appearance reported by Hutchison $e t$ al. and attributed by these workers to a growth hormone effect, as part of a basic hormonal defect in these infants. We think it is more likely due to the effect of excessive insulin.

Assessment of pancreatic islet cell function by serum insulin assays and intravenous tolbutamide tests at the onset and during the course of the illness would be valuable. We can offer no explanation for the apparently anomalous metabolic situation in which there is a failure of carbohydrate utilization without evidence of accumulation of the products of fat katabolism as seen in true diabetes mellitus. Perhaps this is in some way related to the relative absence of subcutaneous fat in babies suffering intrauterine starvation. Against this is the fact that four of the infants were not thin at birth. We are intrigued by the comparison between these infants and newborns suffering from idiopathic hypoglycaemia, who also frequently show evidence of intrauterine starvation.

\section{Summary}

Two cases of idiopathic neonatal hyperglycaemia are presented together with studies of plasma insulin activity, and a brief review of 13 previously reported cases is given. A clinical syndrome affecting mainly dysmature infants emerges.

The insulin studies suggest islet-cell failure or the presence of insulin antagonists rather than failure of "end-organ responsiveness".

Note: Case 2 was shown at the Royal Society of Medicine, Section of Paediatrics Meeting, March 22, 1963 , and an abridged account was published in the Proc. roy. Soc. Med. (Mortimer, 1963).

We are indebted to Dr. Mary J. Wilmers and Dr. Richard H. Dobbs for permission to publish these cases and for their valuable help and criticisms. We would like to thank Dr. Keith Taylor, King's College Hospital and Dr. E. Samols, Royal Free Hospital, for the insulin studies, and the House Officers and Nursing Staff who were so conscientious in the care of these babies and in the collection of specimens.

\section{REFERENCES}

Arey, S. L. (1953). Transient diabetes in infancy. Pediatrics, 11, 140. Baird, J. D., and Farquhar, J. W. (1962). Insulin-secreting capacity in newborn infants of normal and diabetic women. Lancet, 1, 71. 
Brown, R. J. K., and Wallis, P. G. (1963). Hypoglycaemia in the newborn infant. ibid., 1, 1278.

Cuno, F. (1911). Cited by Lawrence and McCance (1931).

Devine, J. (1938). A case of diabetes mellitus in a young infant. Arch. Dis. Childh., 13, 189.

Engleson, G., and Zetterqvist, P. (1957). Congenital diabetes mellitus and neonatal pseudodiabetes mellitus. ibid., 32, 193.

Gans, B. (1954). Diabetes mellitus in an infant aged 39 days. Proc. roy. soc. Med. . 47, 132

Guest, G. M. (1949). Diabetes mellitus in carly infancy, treated without dietary restrictions. Acta paediat. (Uppsala), 38, 196.

Hickish, G. W. (1956). Neonatal diabetes. Brit. med. J., 1, 95.

Hofman-Bang, E. (1954). Diabetic coma in a three weeks old infant - Proc. of Section for Pediatrics and School Hygiene of the Swedish Medical Society. Acta paediat. (Uppsala), 43, 393.

Hutchison, J. H., Keay, A. J., and Kerr, M. M. (1962). Congenital temporary diabetes mellitus. Brit. med. J., 12, 436.

Jeune, M., and Riedweg (1960). Syndrome diabètique transitoire chez un nouveau-né. Pédiatrie, 15, 63.

Keidan, S. E. (1955). Transient diabetes in infancy. Arch. Dis. Childh., 30, 291.

Kitselle, J. F. (1852). Jb. Kinderheilk, 18, 313. Cited by Lawrence and McCance (1931).

Lawrence, R. D., and McCance, R. A. (1931). Gangrene in an infant associated with temporary diabetes. Arch. Dis. Childh., 6, 343.

Lewis, E., and Eisenberg, H. (1935). Diabetes mellitus neonatorum, report of a probable case. Amer. J. Dis. Child., 49, 408.
Limper, M. A., and Miller, A. J. (1935). Diabetes mellitus with extensive gangrene in early infancy. ibid., 50, 1216.

Mortimer, P. E. (1963). Neonatal hyperglycaemia. Proc. roy. Soc. Med., 56, 787.

Nawrocka-Kanska, B. (1952). Diabetic syndrome in the course of intracranial bleeding in the newborn. Pediat. pol., 27, 1067.

Neligan, G. A., Robson, E., and Watson, J. (1963). Hypoglycaemia in the newborn; a sequel of intrauterine malnutrition. Lancet, 1 , 1282.

Ramsey, W. R. (1927). Glycosuria of newborn treated with insulin. Trans. Amer. pediat. Soc. 1926, 38, 100.

Stimmler, L., Brazie, J. V., and O'Brien, D. (1964). Plasma-insulin levels in the newborn infants of normal and diabetic mothers. Lancet, 1, 137.

Strandqvist, B. (1932). Infantile glycosuria simulating diabetes. Acta paediat. (Uppsala), 13, 421.

Sweetnam, W. P., and Sykes, C. G. W. (1962). Congenital diabetes mellitus. Brit. med. J., 11, 671.

\section{Addendum.}

Case 1, at the age of 27 months, still requires a small dese of insulin. He remains free from ketosis and is making satisfactory progress. Further investigations are planned. 